\title{
POPULATION STRUCTURE AND DRIFTING PATTERN OF AQUATIC MITES IN RANDI GAD, A TRIBUTARY OF RIVER ALAKNANDA IN GARHWAL HIMALAYA, UTTARAKHAND, INDIA
}

\author{
Pankaj Bahuguna $^{1^{*}}$ and Anoop Kumar Dobriyal ${ }^{2}$ \\ ${ }^{1}$ Department of Zoology, BD Govt.P.G.College Lansdowne, Jaiharikhal, District Pauri Garhwal, \\ Uttarakhand-246193, India. \\ ${ }^{2}$ Department of Zoology, HNB Garhwal University (A Central University) BGR.Campus, Pauri Garhwal- \\ 246001, Uttarakhand, India.
}

*Corresponding Author Email id: pankajpaurii@gmail.com

Received: 10.8.2020; Revised: 29.9.2020; Accepted: 4.11.2020

CSociety for Himalayan Action Research and Development

\begin{abstract}
The present paper deals with the population structure and temporal drift pattern study of aquatic mites in Randi gad, which is a third order spring fed tributary of river Alaknanda in Garhwal, Uttarakhand, India. The mites contribute significantly to the structure and function of a stream ecosystem as it is a preferred food of fish and insects. To significantly analyze the drift strength of mites in a stream, a new index, Dobriyal Bahuguna Drifting Index (DBDI) has been developed which is based on the density of mite population in nature and number of drifting individuals in unit time. The maximum mite population in the stream was observed in January $\left(51 \mathrm{units}^{-\mathrm{m}^{-2}}\right)$ and minimum in October ( 35 units. $\mathrm{m}^{-2}$ ) with 7 species. It was found that the mites perform specific monthly and diel drift pattern. Various factors like current velocity, breeding, colonization, habitat disturbance and protection from predators are responsible for it. The DBDI value for different mite species was observed highest in February (0.264) and minimum in November (0.227). It was also observed that maximum drift was preferred during late morning hours (8-12 hrs).
\end{abstract}

Keywords: Aquatic mites, Population structure, Drift pattern, Spring-fed Stream, Garhwal Himalaya, DBDI

\section{Introduction}

Aquatic mites form an important community of microbenthos in streams which are generally neglected by the hydrobiologists. They are significant food for benthic as well as nektonic fauna. The knowledge regarding the distribution of aquatic mites from Indian riverine ecosystem is limited and highly fragmentary (Kumar and Dobriyal, 1992; Kumar et.al., 2006, 2007; Pesic et.al., 2007a, 2007b, 2019a, 2019b, 2020a, 2020b). Drifting is a behavior exhibited by the aquatic insects in streams due to various ecophysiological reasons. Lotic ecosystems have strong unidirectional flow of water that transports material from upstream to downstream area and thus helps in the distribution of various aquatic resources. Velocity of water current is perhaps the most important ecological factor that affects the existence of organisms in lotic water bodies. Many invertebrates possess morphological adaptations which help them to avoid being swept away. Nevertheless, many of these organisms move in the water column (actively or passively) and thereafter displace downstream by the current. This phenomenon is known as drift (Waters, 1972; Muller, 1974; Allan, 1995), whereas diel drift periodicity is usually related to predation by visually hunting drift-feeding predators and with their endogenous circadian rhythms, such as 
locomotory rhythms and foraging behavior (Waters, 1972; Flecker, 1992; Huhta et.al., 2000). Research studies have confirmed the diel or annual periodicity of drift depending on several factors which may be habitat and species specific (Anderwald, et.al., 1991; Waringer, 1992), body size (Allan, 1984), altitude (Brewin and Ormirod, 1994) and predation risk (Huhta et.al.,1999).

The present study is a cohesive attempt to examine the population structure, diversity and temporal drift pattern of water mites in a spring fed stream from Garhwal Himalaya. A new drift index (Dobriyal-Bahuguna Drifting Index; DBDI) is also developed which is helpful in analyzing the quantum of drift in a particular time or season.

\section{Material and Methods}

Uttarakhand is a state in a northern part of India with an area of $53,566 \mathrm{~km}^{2}$, of which $73 \%$ is mountainous and $64 \%$ is covered by forest. Most of the northern parts of the state fall in Greater Himalaya range, covered by the high Himalayan peaks and glaciers. The great Ganga river system with two largest rivers the Ganga and Yamuna originate from the glacier of Uttarakhand. River Ganga is formed by the confluence of Bhagirathi (originating from Gomukh glacier) and Alaknanda (originating from Alkapuri glacier) at Devprayag.

Study Area: The study was conducted in Randi Gad stream, which is an important third order spring fed (Latitude $-30^{\circ} 07^{\prime} 06^{\prime \prime} \mathrm{N}$ and $78^{0} 35^{\prime 2} 21^{\prime \prime E}$ ) tributary of Alaknanda River (Fig.1). Randi stream originates from the Ransi and Jhandidhar Peak in the Pauri Garhwal region. A $20 \mathrm{~km}$-long stretch of the stream located upstream from Alaknanda River was chosen as the study area. The mean channel width is 6 meter and the mean depth is $20-60 \mathrm{~cm}$ during the study period from October, 2017 to March, 2018. The substratum of the stream consists of gravel, cobbles and a few boulders. The flow regime of the stream is characterized by narrow seasonal fluctuations excepting flooded monsoon (Bahuguna et.al.,2019).

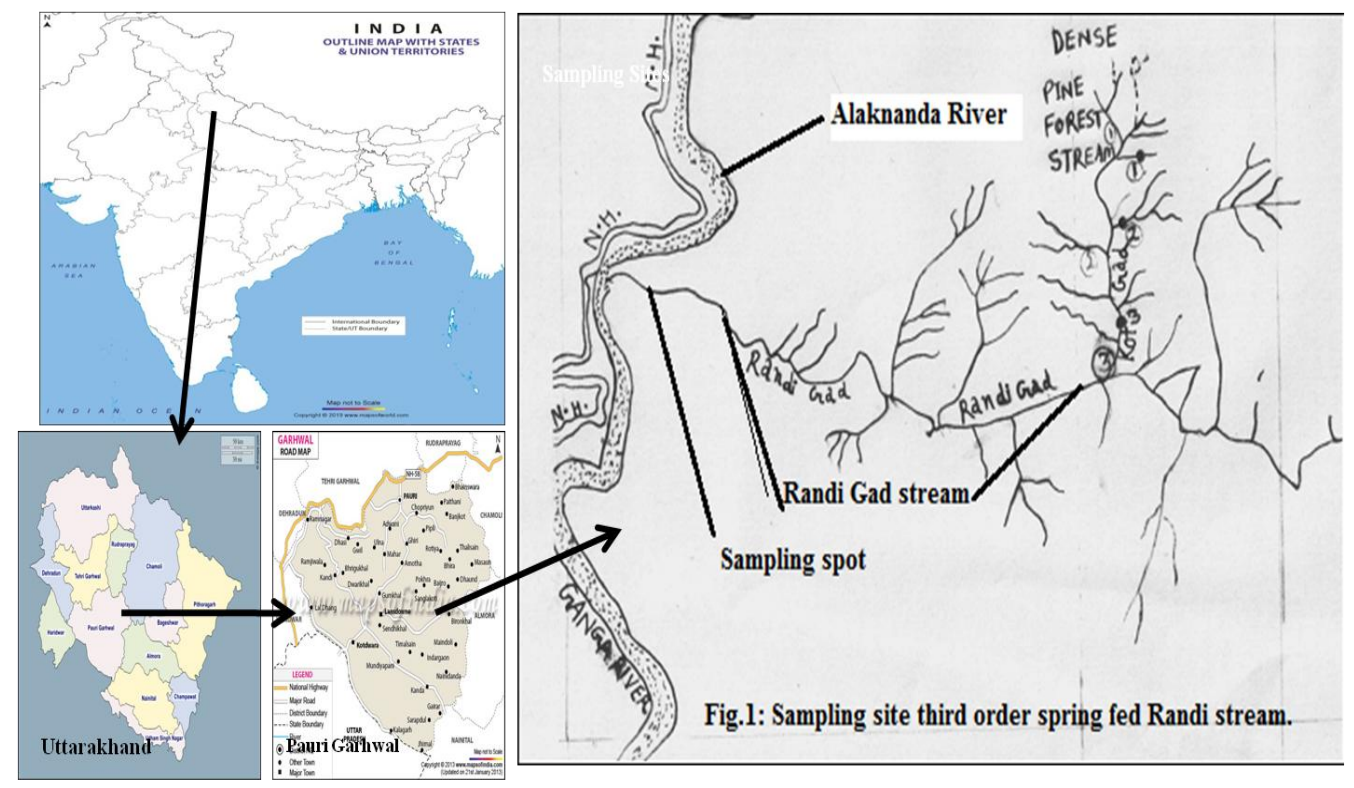

Figure 1: Location of the study spot in Uttarakhand, India

\section{Sampling Design and Analysis}

The study was conducted during the period from October, 2017 to March, 2018. Square framed Surber Sampler was used for sampling mites from
$1 \mathrm{~m}^{2}$ of the stream bed. The mites were preserved on the spot in Koenike's fluid and brought to laboratory for further investigations. For 
sampling of mite drift we designed a new metallic frame drifting net with foot stands that could be adjusted according to depth of the river or stream. The mouth of net was $1 \mathrm{~m}$, which was fixed at a depth of $0.2 \mathrm{~m}$. The average velocity of water current during study period was about $0.2 \mathrm{~m}$. $\mathrm{sec}^{-1}$. Hence the volume of water entering in to net was estimated as $0.04 \mathrm{~m}^{-3} \cdot \mathrm{sec}^{-1}$ for 24 hours. Replicate samples were collected for both studies and an average value was taken in to consideration. The nets were set for 4 hours at a stretch which were immediately replaced by another set as the study was conducted for regular 24 hours. Species identification was done with the help of various keys provided by several authors (Kumar et.al., 2007; Cook,1967, 1974; Prasad,1974; Gerecke, 2003; Pesic and Panesar, 2008)

A new Dobriyal-Bahuguna Drifting Index (DBDI) for aquatic mites was developed on the basis of the density of mite population in nature and number of drifting individuals in unit time.

The formulae for DBDI index was developed as follows:

$$
\text { DBDI }=\sqrt[3]{ }\left(D_{\mathrm{dm}} / \mathrm{T}_{\mathrm{mp}} \cdot \mathrm{T}\right)
$$

Where: D.B.D.I.= Dobriyal-Bahuguna Drifting Index.,

$D_{\mathrm{dm}}=$ No. of drifting mites (units per $0.04 \mathrm{~m}^{3} . \mathrm{sec}^{-}$

${ }^{1}$ for 24 Hours), (i.e., mouth of net $1 \mathrm{~m}$, depth of sampler $0.2 \mathrm{~m}$, current velocity $\left.0.2 \mathrm{~m} \cdot \mathrm{sec}^{-1}\right), \mathrm{T}_{\mathrm{mp}}$ $=$ Total mite population in stream (units. $\mathrm{m}^{-2}$ )

$\mathrm{T}=$ Time used in collecting sample in hours (24) (Note: All values are adjustable depending upon particular cases)

\section{Results}

The Species composition of the aquatic mites (units. $\mathrm{m}^{-2}$ ) and observance of drifting mite species (units. $0.04 \mathrm{~m}^{3} \cdot \mathrm{sec}^{-1}$ for 24 Hours) in the Randi Gad stream during the year 2017-18 is presented in Table 1. A total of seven species were observed in Randi Gad, which is a $3^{\text {rd }}$ order stream. A maximum number of 51 mites $\mathrm{m}^{-2}$ were recorded in the month of January, 2018 and minimum 35 mites. $\mathrm{m}^{-2}$ in October. The highest diel drifting population was observed in the month of March (20) and minimum in October (10).

\section{Density, diversity and taxonomic composition of aquatic mites:}

In the Randi gad stream, Sperchon indicus (62) was recorded as the dominant species followed by the Sperchon hirsutus (46), Torrenticola turkestanica (38), Sperchon garhwaliensis (34), Atractides indicus (29), Feltria gereckei (29) and Kongsbergia indica (22). A total of seven species belongs to five families (Family-SperchontidaeSperchon indicus, S. hirsutus, S. garhwaliensis; Family - Hygrobatidae- Atractides indicus; Family- Feltriidae- Feltria gereckei; FamilyAturidae- Kongsbergia indica and FamilyTorrenticolidae -Torrenticola turkestanica) were observed.

\section{Dobriyal-Bahuguna Drifting Index (DBDI):}

Data related to DBDI and its Monthly variation is shown in Table 2. DBDI value ranged from 0.227 (November) to 0.263 (February). From DBDI value it is revealed that February and March months were conducive for the mite population in Randi gad stream.

\section{Diel drifting behavior:}

Observations on the diel drifting pattern of aquatic mites in Randi Gad stream is presented in the Table 3. Most of the aquatic mites were caught during day time. The Sperchon indicus, Sperchon hirsutus, Atractides indicus, Torrenticola turkestanica and Kongsbergia indica drifted actively during day light hrs (8.0am to $12.0 \mathrm{pm}$ and $12.10 \mathrm{pm}$ to $4.10 \mathrm{pm})$. These mite species showed a clear cut diel pattern in spring fed hill stream. However, Feltria gereckei species drifted during night hrs $(8.30 \mathrm{pm}$ to $12.30 \mathrm{pm})$ and Sperchon garhwaliensis in early morning times (4.50am to 8.0am). 
Table 1: Species composition of the aquatic mites (units. $\mathrm{m}^{-2}$ ) and observance of drifting Mite species (units. $0.04 \mathrm{~m}^{3} . \mathrm{sec}^{-1}$ for 24 hours) in the Randi Gad stream of Garhwal, Uttarakhand

\begin{tabular}{|c|c|c|c|c|c|}
\hline Month & Name of species & $\begin{array}{l}\text { Density of mite } \\
\text { species } \\
\left(\text { units.m- }{ }^{2}\right) \\
\end{array}$ & $\begin{array}{c}\text { Total } \\
\text { density } \\
\left(\mathbf{T}_{\mathbf{m p}}\right) \\
\end{array}$ & $\begin{array}{l}\text { No. of drifting species } \\
\text { (units. } 0.04 \mathrm{~m}^{3} \cdot \mathrm{sec}^{-1} \text { for } \\
24 \text { Hours) }\end{array}$ & $\begin{array}{c}\text { Total drift } \\
\text { D dm }\end{array}$ \\
\hline \multirow{7}{*}{$\begin{array}{l}\text { October, } \\
2017\end{array}$} & Sperchon indicus & 08 & \multirow{7}{*}{35} & 03 & \multirow{7}{*}{10} \\
\hline & Sperchon hirsutus & 06 & & 01 & \\
\hline & Sperchon garhwaliensis & 06 & & 01 & \\
\hline & Torrenticola turkestanica & 08 & & 01 & \\
\hline & Atractides indicus & 02 & & 01 & \\
\hline & Kongsbergia indica & 03 & & 02 & \\
\hline & Feltria gereckei & 02 & & 01 & \\
\hline \multirow{7}{*}{$\begin{array}{l}\text { November, } \\
2017\end{array}$} & Sperchon indicus & 09 & \multirow{7}{*}{39} & 03 & \multirow{7}{*}{11} \\
\hline & Sperchon hirsutus & 09 & & 04 & \\
\hline & Sperchon garhwaliensis & 04 & & 00 & \\
\hline & Torrenticola turkestanica & 06 & & 02 & \\
\hline & Atractides indicus & 01 & & 00 & \\
\hline & Kongsbergia indica & 04 & & 01 & \\
\hline & Feltria gereckei & 06 & & 01 & \\
\hline \multirow{7}{*}{$\begin{array}{l}\text { December, } \\
2017\end{array}$} & Sperchon indicus & 10 & \multirow{7}{*}{46} & 05 & \multirow{7}{*}{17} \\
\hline & Sperchon hirsutus & 08 & & 02 & \\
\hline & Sperchon garhwaliensis & 04 & & 01 & \\
\hline & Torrenticola turkestanica & 04 & & 01 & \\
\hline & Atractides indicus & 09 & & 05 & \\
\hline & Kongsbergia indica & 05 & & 01 & \\
\hline & Feltria gereckei & 06 & & 02 & \\
\hline \multirow{7}{*}{$\begin{array}{l}\text { January, } \\
2018\end{array}$} & Sperchon indicus & 14 & \multirow{7}{*}{51} & 05 & \multirow{7}{*}{17} \\
\hline & Sperchon hirsutus & 05 & & 00 & \\
\hline & Sperchon garhwaliensis & 09 & & 03 & \\
\hline & Torrenticola turkestanica & 07 & & 01 & \\
\hline & Atractides indicus & 08 & & 04 & \\
\hline & Kongsbergia indica & 05 & & 02 & \\
\hline & Feltria gereckei & 03 & & 02 & \\
\hline \multirow{7}{*}{$\begin{array}{l}\text { February, } \\
2018\end{array}$} & Sperchon indicus & 10 & \multirow{7}{*}{43} & 04 & \multirow{7}{*}{19} \\
\hline & Sperchon hirsutus & 10 & & 05 & \\
\hline & Sperchon garhwaliensis & 06 & & 02 & \\
\hline & Torrenticola turkestanica & 08 & & 03 & \\
\hline & Atractides indicus & 03 & & 01 & \\
\hline & Kongsbergia indica & 02 & & 01 & \\
\hline & Feltria gereckei & 04 & & 03 & \\
\hline \multirow{7}{*}{$\begin{array}{l}\text { March, } \\
2018\end{array}$} & Sperchon indicus & 11 & \multirow[t]{7}{*}{46} & 05 & \multirow{7}{*}{20} \\
\hline & Sperchon hirsutus & 08 & & 03 & \\
\hline & Sperchon garhwaliensis & 05 & & 02 & \\
\hline & Torrenticola turkestanica & 05 & & 02 & \\
\hline & Atractides indicus & 06 & & 03 & \\
\hline & Kongsbergia indica & 03 & & 01 & \\
\hline & Feltria gereckei & 08 & & 04 & \\
\hline $\begin{array}{l}\text { Total no. } \\
\text { of mites }\end{array}$ & $\begin{array}{l}\text { Sperchon indicus }=6 \\
\text { garhwaliensis }=34, \text { T. turl } \\
\text { fontinalis }=22, F \text {. gereckei }\end{array}$ & $\begin{array}{l}\text { S. } \quad \text { hirsutus } \\
\text { stanica }=38, \text { A. in } \\
29\end{array}$ & $\begin{array}{c}=46, \quad S . \\
c u s=29,\end{array}$ & $\begin{array}{l}\text { Sperchon indicus }=25, \\
\text { 15, S. garhwaliensis }=09, \\
\text { T. turkestanica }=10, \quad A \\
\text { A.fontinalis }=08, \text { F.gerec }\end{array}$ & $\begin{array}{l}\text { S. hirsutus }= \\
\text { indicus }=14 \text {, } \\
\text { ei }=13\end{array}$ \\
\hline
\end{tabular}


Table 2: Dobriyal-Bahuguna Drifting Index (DBDI) values calculated for the period of October 2017 to March 2018.

\begin{tabular}{|c|c|c|c|c|c|}
\hline Month & $\begin{array}{llr}\text { Ddm } & & \\
\text { (units. } & 0.04 \\
\mathbf{m}^{3} \cdot \text {.sec }^{-1} & \text { for } & 24 \\
\text { Hours) } & & \\
\end{array}$ & $\begin{array}{l}\mathbf{T}_{\mathrm{mp}} \\
\text { (units.m-2 }{ }^{2} \text { ) }\end{array}$ & $\begin{array}{l}\mathbf{T} \\
\text { (Time taken for } \\
\text { sampling) }\end{array}$ & $\left(\mathrm{D}_{\mathrm{dm}} / \mathrm{T}_{\mathrm{mp}} \cdot \mathrm{T}\right)$ & $\begin{array}{l}\text { DBDI }= \\
\sqrt[3]{ } \sqrt{\left(D_{\mathrm{dm}} / \mathrm{T}_{\mathrm{mp}} . \mathrm{T}\right)}\end{array}$ \\
\hline October, 2017 & 10 & 35 & 24 & 0.0119 & 0.228 \\
\hline November, 2017 & 11 & 39 & 24 & 0.0117 & 0.227 \\
\hline December, 2017 & 17 & 46 & 24 & 0.0154 & 0.248 \\
\hline January, 2018 & 17 & 51 & 24 & 0.0139 & 0.240 \\
\hline February, 2018 & 19 & 43 & 24 & 0.0184 & 0.264 \\
\hline March, 2018 & 20 & 46 & 24 & 0.0184 & 0.263 \\
\hline
\end{tabular}

\section{Discussion}

The aquatic mites play a vital role in the aquatic ecosystem as they are an important source of food for small fishes and macrozoobenthos. Their concentration in the system depends on the interrelationship with various ecological factors. Water temperature and velocity were observed as important limiting factors that not only influence the mite diversity but also other interactive physico-chemical characteristics (Kumar and Dobriyal, 1992; Bahuguna et.al.,2019). In the present study of Randi spring fed hill stream, the aquatic mites were recorded maximum in January and minimum in October. During the study period, the abundance of individual species in the stream was due to Sperchon indicus (62), Sperchon hirsutus (46), Torrenticola turkestanica (38), Sperchon garhwaliensis (34), Atractides indicus (29), Feltria gereckei (29) and Kongsbergia indica (22).

Drifting plays a crucial role in spatial distribution of stream aquatic mites. According to Waters (Op.cit.), the drift occurred to keep the population at the carrying capacity. It states that as the organism grows to a certain size, it must drift to a new area to check depletion of the resources in the previously occupied area. He stated that the insects drift in high number at the same time to try and overwhelm their predators thereby increasing the chances for survival. According to Pijanowska
(1999), drift is an important way for individuals to avoid the pressure of predators and to resolve the problem "to eat and not to be eaten". Minshall and Petersen (1985) stated that the drifting is the principal means of recolonizing an area of stream bed after a drought or heavy pollution and of the colonization of substrata suspended in water column.

Different species of mites showed diverse pattern of drifting at different times. Some species also showed zig zag pattern instead of a fixed pattern. In the present study of density (mites. $\mathrm{m}^{-2}$ ), diversity of different aquatic mites and $24 \mathrm{hrs}$ diel drifting numbers of aquatic mites (in the stream Randi gad) were estimated by DBDI Index, which indicates the peak population of mites that actually drifted out of the total population of mites present in the particular place and time.

The DBDI value showed monthly variations for drifting mites in Randi Gad. The drift was maximum in February and minimum in October. Monthly species wise highest value was observed for Atrurus fontinalis in October, for Sperchon hirsutus in November, Atractides indicus in December, Feltria gereckei in January, Feltria gereckei in February and Atractides indicus and Feltria gereckei in March.

During the present work on stream diel drift, we have come out with several patterns that 
Table 3: Observations on the diel drifting pattern of aquatic mites in Randi Gad stream (units. 0.04 $\mathrm{m}^{3} \cdot \mathrm{sec}^{-1}$ for 24 hours).

\begin{tabular}{|c|c|c|c|c|c|c|c|}
\hline Month & Name of species & $\begin{array}{c}\text { 8.0am to } \\
12.0 \mathrm{pm}\end{array}$ & $\begin{array}{c}12.10 \mathrm{pm} \text { to } \\
4.10 \mathrm{pm}\end{array}$ & $\begin{array}{l}4.20 \mathrm{pm} \mathrm{to} \\
8.20 \mathrm{pm}\end{array}$ & $\begin{array}{c}\text { 8.30pm to } \\
12.30 \mathrm{am}\end{array}$ & $\begin{array}{c}\text { 12.40am to } \\
\text { 4.40am }\end{array}$ & $\begin{array}{l}4.50 a \\
\text { m to } \\
\text { 8.0am }\end{array}$ \\
\hline \multirow{7}{*}{$\begin{array}{l}\text { Oct, } \\
2017\end{array}$} & Sperchon indicus & 2 & 1 & - & - & - & - \\
\hline & Sperchon hirsutus & - & 1 & - & - & - & - \\
\hline & Sperchon garhwaliensis & - & - & - & - & - & 1 \\
\hline & Torrenticola turkestanica & 1 & - & - & - & - & - \\
\hline & Atractides indicus & 1 & - & - & - & - & - \\
\hline & Kongsbergia indica & 1 & 1 & - & - & - & - \\
\hline & Feltria gereckei & - & - & - & 1 & - & - \\
\hline \multirow{7}{*}{$\begin{array}{l}\text { Nov, } \\
2017\end{array}$} & Sperchon indicus & 2 & 1 & - & - & - & - \\
\hline & Sperchon hirsutus & 3 & 1 & - & - & - & - \\
\hline & Sperchon garhwaliensis & - & 0 & - & - & - & - \\
\hline & Torrenticola turkestanica & 2 & - & - & - & - & - \\
\hline & Atractides indicus & 0 & - & - & - & - & - \\
\hline & Kongsbergia indica & 1 & - & - & - & - & - \\
\hline & Feltria gereckei & - & - & - & 1 & - & - \\
\hline \multirow{7}{*}{$\begin{array}{l}\text { Dec, } \\
2017\end{array}$} & Sperchon indicus & 2 & 3 & - & - & - & - \\
\hline & Sperchon hirsutus & 1 & 1 & - & - & - & -- \\
\hline & Sperchon garhwalienis & - & - & - & - & - & 1 \\
\hline & Torrenticola turkestanica & 1 & - & - & - & - & - \\
\hline & Atractides indicus & 2 & 3 & - & - & - & - \\
\hline & Kongsbergia indica & 1 & - & - & - & - & - \\
\hline & Feltria gereckei & - & - & - & 2 & - & - \\
\hline \multirow{7}{*}{$\begin{array}{l}\text { Jan, } \\
2018\end{array}$} & Sperchon indicus & 2 & 3 & - & - & - & - \\
\hline & Sperchon hirsutus & - & - & - & - & - & - \\
\hline & Sperchon garhwaliensis & - & - & - & 1 & - & 2 \\
\hline & Torrenticola turkestanica & 1 & - & - & - & - & - \\
\hline & Atractides indicus & 2 & 2 & - & - & - & - \\
\hline & Kongsbergia indica & 1 & 1 & - & - & - & - \\
\hline & Feltria gereckei & - & - & - & 2 & - & - \\
\hline \multirow{7}{*}{$\begin{array}{l}\text { Feb, } \\
2018\end{array}$} & Sperchon indicus & 2 & 2 & - & - & - & - \\
\hline & Sperchon hirsutus & 2 & 3 & - & - & - & - \\
\hline & Sperchon garhwaliensis & - & - & - & - & - & 2 \\
\hline & Torrenticola turkestanica & 3 & - & - & - & - & - \\
\hline & Atractides indicus & 1 & - & - & - & - & - \\
\hline & Kongsbergia indica & 1 & - & - & - & - & - \\
\hline & Feltria gereckei & - & - & - & 3 & - & - \\
\hline \multirow{7}{*}{$\begin{array}{l}\text { Mar, } \\
2018\end{array}$} & Sperchon indicus & 3 & 2 & - & - & - & - \\
\hline & Sperchon hirsutus & 2 & 1 & - & - & - & - \\
\hline & Sperchon garhwaliensis & - & 1 & - & - & - & 1 \\
\hline & Torrenticola turkestanica & 2 & - & - & - & - & - \\
\hline & Atractides indicus & 2 & 1 & - & - & - & - \\
\hline & Kongsbergia indica & 1 & - & - & - & - & - \\
\hline & Feltria gereckei & - & - & - & 4 & - & - \\
\hline
\end{tabular}

showed how the aquatic mite species tend to drift throughout the day. There was a general preference for day time drift rather than drift during dark or night hours. In Sperchon indicus (13), Torrenticola turkestanica (11), Sperchon hirsutus (08) and Kongsbergia indica (06) diel drifting rate was noted maximum during the morning (8.0am to12.0pm) period. These were most abundant in the substrate of stream. The aquatic mite species viz. Sperchon indicus (12), Atractides indicus (07), Sperchon hirsutus (6) and Kongsbergia indica (02) also showed drifting during day time (12.10 pm to $4.10 \mathrm{pm})$. However, 
In Feltria gereckei (13 aquatic mites) species; diel drifting pattern was observed at night time (8.30pm to12.30am) and in Sperchon garhwaliensis (7) during dawn (early morning4.50am to 8.0am) period in Randi Gad stream. It can be concluded from the present investigation that particular species showed specific diel drifting pattern.

The species wise peak values were observed due to diverse response of drifting of the aquatic mites species to various factors like colonizing new habitat and distribute among patchy habitats (Allan,1995), species -specific life cycle (Elliott,1967), breeding , feeding behavior (Waters, Op.cit.), reformation of colonies, habitat disturbance and protection from predators (Huhta et.al.,1999). Differences in the geo-morphology of the streams also affect the drifting behaviour of the mites. Hynes (1970) suggested that several factors such as the water current, temperature, substratum, vegetation, and dissolved substances, liability to drought and floods, food, competition between species, shade and zoogeography regulate the occurrence and distribution of stream invertebrates. Present study also concluded that current velocity is a detrimental factor for drift.

\section{Acknowledgements}

Author (PB) gratefully acknowledge the financial assistance rendered by Science and Engineering Research Board (SERB) under a major Project No. ECR/2016/001291. Authors are grateful to Prof John Brittain, Emeritus Senior Research Scientist, University of Oslo, Norway for giving important suggestions regarding drift studies on mites. Two anonymous referees are also thankfully acknowledged for their careful work and valuable comments.

\section{References}

Allan JD (1984) The size composition of invertebrate drift in a rocky mountain (Colorado, USA) stream. Oikos 43: 68-76.

Allan JD (1995) Drift. In: Stream ecologystructure and function of running waters (Ed.
J.D. Allan) Chapman and Hall, London. pp 221-237.

Anderwald PH, Konar $\mathrm{M}$ and Humpesch UH (1991) Continuous drift sample of macroinvertebrate in a large river, the Danube in Austria. Freshw. Biol. 25: 461476.

Bahuguna P, Negi S and Dobriyal AK (2019) Density and diversity of aquatic mites in a spring fed stream of Garhwal Himalaya, India. J. Mountain Res. 14(2): 57-61.

Brewin PA and Ormerod SJ (1994) Macroinvertebrate drift in streams of the Nepalese Himalaya. Freshw. Biol. 32:573583.

Cook DR (1967) Water mites from India. Memoirs of the American Entomological Institute, 9: 1-411

Cook DR (1974) Water mite genera and subgenera. Memoirs of the American Entomological Institute, 21: 1-860

Elliott J M (1967) Invertebrate drift in a Dartmoor stream. Archiv fur Hydrobiol. 63:202-237.

Flecker AS (1992) Fish predation and the evolution of invertebrate drift periodicity: evidence from Neotropical streams. Ecology 73: 438-448.

Gerecke R (2003) Water mites of the genus Atractides Koch, 1837 (Acari: Parasitengona: Hygrobatidae) in the western Palaearctic region: a revision. Zoological J. Linnean Soc. 138: 141-378.

Huhta A, Muotka T and Tikkanen P (2000). Nocturnal drift of mayfly nymph as a postcontact antipredator mechanism. Freshw. Biol. 45: 33-42.

Huhta A, Muotka T, Juntunen A and Yrjonen, M. (1999) Behavioural interactions in stream food webs: the case of drift-feeding fish, predatory invertebrates and grazing mayflies. J Animal Eco. 68: 917-927.

Hynes H B N (1970). The Ecology of running waters. Liverpool University Press.

Kumar N and Dobriyal AK (1992) Some observations on the water mites of a Hill stream Khanda gad in Garhwal Himalaya. $J$. Freshwater Biol. 4: 193-197. 
Kumar N, Kumar K and Pesic V (2007) Two new species of Sperchon Kramer (Acari: Hydrachnidia: Sperchontidae) from the Garhwal Himalayas (India). Syst. Appl. Acarol., 12:31-36.

Kumar N, Kumar K, Kumar S and Pesic V (2006) Monatractides tuzovskyi sp.nov. (Acari: Torrenticolidae), A new water mite species from the Garhwal Himalayas (India). Acarina 14 (2):81-83.

Minshall G W and Petersen R C (1985) Towards a theory of macroinvertebrate community structure in stream ecosystems. Archiv fur Hydrobiol. 104: 49 -76.

Muller K (1974) Stream drift as a chronobiological phenomenon in running water ecosystems. Annu Rev Ecol Systema 5: 309-323.

Pesic V, Smit H, Bahuguna P (2020a) A new species of Kongsbergia from the Western Himalaya with a key to the species of the genus of India (Acari: Hydrachnidia). Ecologica Montenegrina 27: 35-38.

Pesic V, Smit H, Negi S, Bahuguna, $\mathrm{P}$ and Dobriyal AK (2020b) Torrenticolid water mites of India with description of three new species (Acari: Hydrachnidia, Torrenticolidae). Syst. Appl. Acarol., 25(2):255-267.

Pesic V and Panesar A (2008) Studies on water mites (Acari: Hydrachnidia) from the Himalayas, I. The water mites genus Feltria Koenike, with description of eight new species. Zootaxa 2119:1-22.

Pesic V, Kumar N and Kumar K (2007a) Two new species of water mites of the family Hygrobatidae (Acari: Hydrachnidia) from the Garhwal Himalayas (India). Syst. Appl. Acarol., 12: 161-166.

Pesic V, Kumar N and Kumar K (2007b) A new species of Monatractides (Acari: Hydrachnidia: Torrenticolidae) and new records of other torrenticolid water mites from the Garhwal Himalayas (India). Syst. Appl. Acarol., 12(3-4): 205-212.

Pesic V, Smit H and Bahuguna P (2019a) New records of water mites (Acari: Hydrachnidia) from the Western Himalaya with the description of four new species. Syst. Appl. Acarol., 24(1): 59-80.

Pesic V, Smit H and Bahuguna P (2019b) New records of water mites (Acari: Hydrachnidia) from the Western Himalaya and description of three new species from Asia. Syst. Appl. Acarol., 24(10): 1868-1880.

Pijanowska J (1999) Predation ecology in aquatic environment. Kosmos 48:401-526.

Prasad V (1974) A catalogue of mites of India. Indira Acarology Publishing House, Ludhiana.

Waringer J A (1992) The drifting of invertebrates and particulate organic matter in an Austrian mountain brook. Freshw. Biol. 27:367-378.

Waters TF (1972) The drift of stream insects. Ento. Ann. Rev. California 17: 253-272.
$* * * * * * * * *$ 